\title{
Identification for Sources of Resistance to Biotic Stresses in Mothbean [Vigna aconitifolia (Jaeq.) Marcchal] Germplasm
}

\author{
Kartar Singh $^{1 *}$, Neelam Shekhawat ${ }^{1}$, Om Vir Singh ${ }^{1}$, \\ Manoj Choudhary ${ }^{2}$ and Dama Ram ${ }^{3}$
}

\author{
${ }^{1}$ ICAR-National Bureau of Plant Genetic Resources, Regional Station, Jodhpur-342003, India \\ ${ }^{2}$ ICAR-National Center for Integrated Pest Management, New Delhi-12, India \\ ${ }^{3}$ Agricultural University Jodhpur-342304, India \\ *Corresponding author
}

\section{A B S T R A C T}

Ke y w o r d s
Mothbean
germplasm, leaf
crinkle virus,
yellow mosaic
virus, cercospora
leaf spot

Mothbean germplasm consisting of 180 accessions were screened against yellow mosaic virus leaf crinkle virus and cercospora leaf spot under the natural field conditions to identify sources of resistance. Based on a consistent observation for 4 different crop seasons germplasm was grouped in accordance with their field reaction. IC-36522 and IC-36217 were found to be the most field promising accession against yellow mosaic virus. IC39786 and IC-39822 were found to be the most field promising accession against leaf crinkle virus under the resistant category. The study also revealed accession IC-16218 free from the natural incidence of cercospora leaf spot, which appeared to be promising. These field promising accessions would most certainly be useful in developing disease resistant cultivars having good agronomic traits and highly productive genetic potential.

\section{Introduction}

Mothbean (Vigna aaconitifolia (Jacq.) Marechal) is an important pulse crop of arid and semi-arid zones of Rajasthan where erratic rainfall and dry atmosphere often lead to poor yield. The low productivity is also due to lack of suitable genotypes and cultural practices (Kumar el al. 1998). It is one of the most drought-hardy and high-temperature tolerant crop among the arid grain legumes cultivated in rainy season (kharif). Earliness along with high yield is of prime importance in drought hit areas. In India, mothbean is being cultivated over an area of 9.256 lakh hectares and production at 2.77 lakh tones 
during 2015-16 (Anonymous, 2016). However, mothbean may not be rated as a national pulse, for instance, its national contribution to pulses is hardly $4 \%$ in area and $2 \%$ in production; on the contrary, it appears to be a major pulse, as far the hot and dry regions of India are concerned. Mothbean, a known drought hardy pulse, is important source of grain and fodder. Crop is endowed with ability to fix atmospheric nitrogen through symbiosis with the Rhizobium strains, which are adapted to the neglected lands and harsh environment.

Inspite of inherent practical potential, embodied in this crop, production in problematic arid regions is considerably affected due to obvious agroclimatic reasons, poor soil fertility status and the ravages of diseases and insect pest problems. Moth bean has been so neglected as far disease management is concerned that, it has inspired few articles on practical diseases management during past half decade. However, there are a number of pathogens which affect moth bean crop causing substantial yield and quality losses to grain and fodder produce. The biotic stresses like yellow mosaic virus, leaf crinkle virus and cercospora leaf spot are major limiting factors for high yield.

Among these, Yellow mosaic disease (YMD) is caused by Mungbean yellow mosaic virus (MYMV), is a most destructive disease of mothbean. Yellow mosaic disease affects many legumes in India and other south Asian countries and is caused by whitefly (Bemisia tabaci Genn.) transmitted by Gemini viruses (Nene, 1972). Yellow mosaic virus (YMV) is the most destructive viral disease affecting yield potential of mothbean both qualitatively and quantitatively and ability to cause yield loss up to 85\% (Nene, 1972; Varma and Malathi, 2003). MYMV belongs to genus Begomovirus of the family Geminiviridae (Varma and Malathi, 2003).
The virus has geminate particle morphology $(20 \mathrm{x} 30 \mathrm{~nm})$ and the coat protein encapsulates spherical, single stranded DNA genome of approxi-mately $2.8 \mathrm{~Kb}$ (Hull, 2004). It occurs in a number of leguminous plants such as mungbean, urdbean, mothbean, cowpea (Nariani, 1960, Nene, 1973), soybean (Suteri, 1974), horsegram (Muniyappa et al., 1975), lab-lab bean (Capoor and Varma, 1948) and French bean (Singh, 1979). In mothbean, MYMV causes irregular yellow green patches on older leaves and complete yellowing of young leaves of susceptible varieties (Singh and De, 2006).

Initially the disease appears as a small yellow patches or spots on green lamina. The young leaves are the first to show the symptoms. The yellow discoloration slowly increases and newly formed leaves may completely turn yellow. The infected plants normally mature later and bear very few flowers and pods. Evaluation of germplasm entries for disease resistance is a crucial step in controlling plant diseases through host plant resistance. Therefore, in present investigation an attempt was made to screen mothbean germplasm against YMD under natural environmental conditions, where high population of viruliferous white fly is always present.

Mothbean is also highly susceptible to another virus infection leaf crinkle disease caused by urdbean leaf crinkle virus (ULCV) (Kadian, 1980, Rishi, 1990). Thus the disease is economically important, destructive, wide spread and inflicts heavy losses annually. It was observed that the incidence of ULCV was relatively higher at the Research Stations than at the farmer's fields and this variation may be attributed to low level of seed transmission in farmer's seed stocks and high number of accessions evaluated by the breeders and pathologists at the stations. The disease is characterized by the appearance of extreme crinkling, curling, puckering and rugosity of 
leaves, stunting of plants and malformation of floral organs. Pollen fertility and pod formation is severely reduced on infected plants (Nene, 1972). The virus has been reported to decrease grain yield from 35 to $81 \%$ depending upon genotype and time of infection (Bashir et al., 1991). ULCV is transmitted through sap inoculation, seeds and insects (Nene, 1972; Kadian, 1980).

According to Ahmad et al., (1997) ULCV is transmitted through seed at the rate of 2.7 to $46 \%$ in urdbean. Leaf feeding beetle (Henosepilachna dodecastigma (Wied), whitefly (Bemisia tabaci Glov.) and two aphid species (Aphis craccivora and $A$. gossypii) have been reported to be putative vectors of ULCV (Beniwal \& Bharathan1980, Narayansamy \& Jaganthan1973, Dhingra, 1975). Leaf spot of mothbean caused by Cercospora canescens is distributed by spores of infected leaves. The fungi form brown spot with white or gray center surrounded by reddish brown margins. The disease is encountered during the rainy season of relatively hot and high humid conditions (Poehlman, 1991). The damages reduce mothbean yield by 47\% (AVRDC, 1984).

Chinsawangwattanakul et al., (1981) also reported that under favorable conditions coupling with sufficient amount of fungal spores, mungbean was severely and rapidly infected resulting in yield reduction as occuring in the susceptible Uthong 1 and resistant Pagasu varieties to 68 and $35 \%$ respectively. Genetical studies revealed 1 pair of genes controlling leaf spot resistance with resistance dominant over susceptibility (Thakur et al., 1980; Laosuwan, 1988). However, the report of Leabwon and Oupadissakoon (1984) stated the leaf spot resistance to be controlled by additive gene with capacity to transmit 99 and $75 \%$ of broad and narrow senses respectively. Inspite of severe disease problems, the attempts on disease management through chemicals have not been undertaken at the farmer's level but practically management strategies being employed, are the use of tolerant genotypes to some extent only.

The solution for management of biotic stresses lies in screening and identification of resistant genotypes that could be adopted into a disease management strategy on a sustained basis. Keeping in view this important component of integrated disease management, efforts were made to screen 180 accs. of mothbean germplasm of indigenous origin from India, to identify promising accessions under natural infestation conditions.

\section{Materials and Methods}

The study was conducted in the research area of ICAR-National Bureau of Plant Genetic Resources Regional Station, Jodhpur for four consecutive Kharif seasons from 2012 to 2016. Well levelled plot with satisfactory drainage system was selected for the experiment.

The mothbean germplasm consisting of 180 accessions along with four check varieties viz., Jadiya, Jawala, RMO-40 and FMM-12-6134 were screened against major biotic stresses like yellow mosaic virus, leaf curl virus and cercospora leaf spot under natural field conditions. Each test entry was sown in a row of 2 meter in length with $50 \mathrm{~cm}$ row-torow distance and replicated 3 times.

General cultural practices were adopted to maintain the experiment except that plant protections chemicals sprays were not applied in order to encourage the population of whitefly for natural disease spreading. The spread of disease in the experimental plot was recorded after germination of plants regularly at 7-day intervals on visual symptoms until maximum infection was achieved. 
Plants showing disease symptoms were counted and percent infection was calculated. Observations on the disease incidence were taken on randomly selected five plants of each entry and took a mean of each entry to assign the category. Observations on YMV were recorded by using a 1 to 9 point rating scale (Singh et al., 1992) as given below (Table 1). Disease incidence rating for leaf curl virus was based on a 1-5 arbitrary scale (Table 2), as suggested by Ashfaq et al., (2007). Disease incidence rating for cercospora leaf spot was based on 1-9 point rating scale (Table 3) suggested by Singh et al., (1988). All the plants in an accession were scored on a particular disease rating scale based on which the per cent disease index (PDI) was calculated with the following formula: Per cent disease index $(\mathrm{PDI})=[$ Sum of disease scales of all plants scored/ (Total no. of plants $\mathrm{X}$ Max. disease scale)] x 100. The mothbean germplasm was grouped based on the pooled mean PDI for four seasons in to different categories viz., resistant (0-10); moderately resistant (11-20); moderately susceptible (2130); susceptible (31-50) and highly susceptible (51-100).

\section{Results and Discussion}

The screening results indicate that there is considerable variability among the collections for resistance. The manifestation of degree of disease incidence which depends up on the build-up of favourable environmental conditions and inoculum levels, varied for all the biotic stresses. The reaction of mothbean germplasm against yellow mosaic virus, leaf curl virus and cercospora leaf spot are given in Table 4. Out of the three biotic stresses, the maximum disease incidence (PDI) of 92 was recorded for yellow mosaic virus and the minimum with 62 for cercospora leaf spot. Promising accessions identified against important biotic stresses are listed here in table 5. The reaction of mothbean germplasm against each of the diseases is summarized here under.

\section{Yellow mosaic virus}

Incidence of Yellow mosaic virus caused by Mungbean yellow Mosaic Virus (MYMV) results in severe losses both in yield and quality of the produce and therefore is a major constraint in mothbean production. Yellow mosaic virus incidence ranged from 7.8 to 92 among the germplasm accs. screened. The screening results indicated that $1.1 \%$ of the accs. were resistant, $6.11 \%$ moderately resistant, $10 \%$ moderately susceptible, $27.22 \%$ susceptible and $50.0 \%$ highly susceptible to field incidence of yellow mosaic virus. The study revealed IC-36522 and IC-36217 with a PDI of 7.8 as the most promising field resistant entry.

\section{Leaf crinkle virus}

Leaf crinkle incidence ranged between 3.4 to 86 among the germplasm accs. screened. The screening results indicated that $1.1 \%$ of the accs. were reported as resistant, $3.33 \%$ moderately resistant, $21.11 \%$ moderately susceptible, $38.88 \%$ susceptible and $35.55 \%$ highly susceptible to field incidence of leaf crinkle virus. The study revealed IC-39786 and IC-39822 with a PDI of 3.4 as the most promising field resistant entry.

\section{Cercospora leaf spot}

Cercospora leaf spot incidence ranged between 1.3 to 62 among the germplasm accs. screened. The screening results indicated that $0.66 \%$ of the accs. were reported as resistant, $9.44 \%$ moderately resistant, $28.33 \%$ moderately susceptible, $43.33 \%$ susceptible and $18.33 \%$ highly susceptible to field incidence of Cercospora canescens. The study revealed IC-16218 with a PDI of 1.3 as the most promising field resistant entry. 
Table.1 Disease rating scale (1-9) for MYMV

\begin{tabular}{|c|c|c|}
\hline Rating & Percentage foliage affected & Reaction \\
\hline 1 & $\begin{array}{c}\text { No visible symptoms or minute yellow specks } \\
\text { covering } 0.1-5 \% \text { leaf area }\end{array}$ & Resistant \\
\hline 3 & Mottling of leaves covering 5.1-15\% leaf area & Moderately resistant \\
\hline 5 & $\begin{array}{l}\text { Yellow mottling and discoloration of } 15.1-30 \% \text { leaf } \\
\text { area }\end{array}$ & Moderately susceptible \\
\hline 7 & $\begin{array}{l}\text { Pronounced yellow mottling and discoloration of } \\
\text { leaves, pods, reducing in leaf size, stunting of plants, } \\
30.1-75 \% \text { foliage affected }\end{array}$ & Susceptible \\
\hline 9 & $\begin{array}{l}\text { Severe yellow mottling and discoloration of leaves, } \\
\text { stunting of plants, failure of flowering and fruit } \\
\text { setting, } 75.1-100 \% \text { foliage affected }\end{array}$ & Highly susceptible \\
\hline
\end{tabular}

Table.2 Disease rating scale (1-5) for leaf crinkle virus

\begin{tabular}{|c|c|c|}
\hline Rating & Percentage foliage affected & Reaction \\
\hline 1 & $\begin{array}{l}1-10 \% \text { plants infected showing mild crinkling at the } \\
\text { top, pods normal }\end{array}$ & Resistant \\
\hline 2 & $\begin{array}{l}11-20 \% \text { plants infected showing crinkling and } \\
\text { curling of top leaves, pods normal }\end{array}$ & Moderately resistant \\
\hline 3 & $\begin{array}{l}21-30 \% \text { plants infected with crinkling, puckering, } \\
\text { malformation, shortening of pods }\end{array}$ & Moderately susceptible \\
\hline 4 & $\begin{array}{c}31-40 \% \text { plants infected showing all the typical } \\
\text { disease symptoms }\end{array}$ & Susceptible \\
\hline 5 & $\begin{array}{c}\text { More than } 40 \% \text { plants infected, with all plants } \\
\text { showing severe symptoms, few pods containing few } \\
\text { seeds }\end{array}$ & Highly susceptible \\
\hline
\end{tabular}

Table.3 Disease rating scale (1-9) for cercospora leaf spot

\begin{tabular}{|c|c|c|}
\hline Rating & \% disease intensity on leaves & Reaction \\
\hline $\mathbf{1}$ & $0.1-5.0$ & Resistant \\
\hline $\mathbf{3}$ & $5.1-15.0$ & Moderately resistant \\
\hline $\mathbf{5}$ & $15.1-30.0$ & Moderately susceptible \\
\hline $\mathbf{7}$ & $30.1-75.0$ & Susceptible \\
\hline $\mathbf{9}$ & $75.1-100.0$ & Highly susceptible \\
\hline
\end{tabular}


Table.4 Reaction of mothbean germplasm against biotic stresses

\begin{tabular}{|l|c|c|c|c|c|c|}
\hline & \multicolumn{5}{|c|}{ Reactions of germplasm (No. of accessions) } \\
\hline Disease & $\begin{array}{c}\text { Incidence } \\
\text { (PDI } \\
\text { range) }\end{array}$ & Resistant & $\begin{array}{c}\text { Moderately } \\
\text { resistant }\end{array}$ & $\begin{array}{l}\text { Moderately } \\
\text { Susceptible }\end{array}$ & Susceptible & $\begin{array}{c}\text { Highly } \\
\text { susceptible }\end{array}$ \\
\hline YMV & $7.8-92$ & 2 & 11 & 18 & 49 & 90 \\
\hline $\begin{array}{l}\text { Leaf } \\
\text { crinkle }\end{array}$ & $3.4-86$ & 2 & 6 & 38 & 70 & 64 \\
\hline $\begin{array}{l}\text { Cercospora } \\
\text { leaf spot }\end{array}$ & $1.3-62$ & 1 & 17 & 51 & 78 & 33 \\
\hline
\end{tabular}

Table.5 Promising accessions identified against important fungal biotic stresses

\begin{tabular}{|l|c|c|}
\hline S. No. & Biotic stress & Promising accessions identified \\
\hline $\mathbf{1}$ & Yellow mosaic virus & IC-36522 and IC-36217 \\
\hline $\mathbf{2}$ & Leaf crinkle virus & IC-39786 and IC-39822 \\
\hline $\mathbf{3}$ & Cercospora leaf spot & IC-16218 \\
\hline
\end{tabular}

The field screening results indicate that there is significant genetic variability in the overall mothbean germplasm collections for degree of resistance to different pathogens. Significant sources of resistance could be identified in yellow mosaic virus, leaf cinkle virus and cercospora leaf spot.

It was observed that the manifestation and degree of disease incidence was very low in case of cercospora leaf spot for drawing meaningful conclusions. The resistant sources in the primary gene pool of cultivated mothbean are ideal for utilization in crossing programmes and incorporation of the resistance in to desirable backgrounds for developing resistant inbreds/ varieties/ hybrids.

\section{References}

Ahmad, Z., Bashir, M. and Mtsueda, T. (1997). Evaluation of legume germplasm for seedborne viruses. In: Harmonizing Agricultural Productivity and Conservation of
Biodiversity: Breeding and Ecology. Proc. $8^{\text {th }}$ SABRAO J. Cong. Annu. Meeting Korean Breeding Soc., Seoul, Korea., pp. 117-120.

Anonymous, (2016). PULSES IN INDIA: RETROSPECT AND PROSPECTS. Govt. of India, New Delhi, DPD/Pub.1/Vol. 2. Pp.111.

Ashfaq, M. Khan, M.A. Mughal, S.M. Javed N,, et al., (2007). Evaluation of urdbean germplasm for resistance against urdbean leaf crinkle virus. Pakistan Journal of Botany 39: 2103-2111.

Bashir, M, Mughal, S.M. and Malik, B.A. (1991). Assessment of yield losses due to leaf crinkle virus in urdbean (Vigna mungo (L) Hepper). Pakistan Journal of Botany 23: 140-142.

Beniwal, S. P. S. and Bharathan, N. (1980). Beetle transmission of urdbean leaf crinkle virus. Indian Phytopathol., 33(4): 600-601.

Capoor, S.P. and Varma, P.M.(1948). A new virus disease of Dolichos lablab. Current Science.19:248-249.

Chinsawangwattanakul, A., Yinasawapun, S. Pichitporn, S. and Surin, P. (1981). Yield loss of mungbean due to Cercospora leaf 
spot, pp. 148. In Annual Report. 1981. Plant Pathology and Microbiology Division, Department of Agricalture, Bangkok, Thailand.

Dhingra, K.L. (1975). Transmission of urdbean leaf crinkle virus by two aphid species. Indian Phytopathol., 28(1): 80-82.

Hull, R. (2004). Mathew's Plant Virology, 4th ed., Elsevier Pub-lishers, India, 180-182.

Kadian, O.P. (1980). Studies on leaf crinkle disease of urdbean (Vigna mungo (L.) Hepper), mungbean (Vigna radiata (L.) Wilczek) and its control. Ph.D. thesis, Department of Plant Pathology, Haryana Agriculture University, Hisar.

Kumar, D., Tarafdar, J.C. and Praveen-Kumar (1998). Variability of Growth, Yield and Nutrient Concentration in Moth Bean (Vigna aconitifolia (Jacq) Marechal) on Arid Lands, Annals of Arid Zone 37(4): 395-400.

Laosuwan, P. (1988). Genetic studies in mungbean. Songklanakarin, Journal of Science and Technology 7: 99-105.

Leabwon, U. and Oupadissakoon, S. (1984). Inheritance of resistance to Cercospora leaf spot in mungbean. Kasetsart J. (Nat. Sci)18:14-19.

Muniyappa, V., Reddy, H.R. and Shivashankar, C. (1975). Yellow mosaic disease of Dolichos biflorus Linn. Current Research. 4: 176.

Narayansamy, P. and Jaganthan, T. (1973). Vector transmission of black gram leaf crinkle virus. Madras Agriculture Journal., 60(7): 651-652.

Nariani, T.K. (1960). Yellow mosaic of mung (Phaseolus aureus). Indian Phytopathology. 13: 24-29.

Nene, Y. L. (1972). Survey of viral diseases of pulse crops in Uttar Pradesh. G.B. Pant University of Agriculture and Technology, Pantnagar, India. Research Bulletin. No 4: 191pp.
Nene, Y.L. (1973). Viral diseases of some warm weather pulse crops in India. Plant Disease Reporter. 57: 463- 467.

Poehlman, J.M. (1991). The Mungbean. Oxford and IBH Publishing Co. PVT. LTD., New Delhi. pp. 375

Rishi, N. (1990). Seed and crop improvement of northern Indian pulses (Pisum and Vigna) through control of seed- borne mosaic viruses Final Technical Report, (US-India Fund) Dept. Plant Pathology, CCS Haryana Agric. Univ. Hisar, India: pp.122

Singh, R.N. (1979). Natural infection of bean (Phaseolus vulgaris) by mungbean yellow mosaic virus. Indian Journal of Mycology and Plant Pathology.9:124-126.

Singh, R.A. and De, R.K. (2006). Major diseases and their management. In: M. Ali and S. Kumar (eds), Advances in Mungbean and Urdbean. 283-334.IIPR, Kanpur.

Singh, G., Singh, K., Gill, A.S. and Chhabra, K.S. (1980). Screening sources of resistance to yellow mosaic virus of mungbean, Vigna radiate L. Wilczek. In: Proceedings of national seminar on disease resistance in crop plants. Tamil Nadu Agric. Univ. Coimbatore. Dec. 22-23. Pp. 72-76.

Singh, G., Sharma, Y.R. and Kaur, L. (1992). Method of rating yellow mosaic virus of mungbean and urdbean. Plant Disease Research 7:1-6.

Suteri, B.D. (1974). Occurrence of soybean yellow mosaic virus in Uttar Pradesh. Current Science.43:689-690.

Thakur, R.P., Patel, P.N. and Verma, J.P. (1980). Inheritance of resistance to Cercospora leaf spot in mungbean. Indian Phytopathology, 33: 377-379.

Varma, A. and Malathi, V.G. (2003). Emerging geminivirus problems: a serious threat to crop production. Annals of Applied Biology.142:145-164.

\section{How to cite this article:}

Kartar Singh, Neelam Shekhawat, Om Vir Singh, Manoj Choudhary and Dama Ram. 2020. Identification for Sources of Resistance to Biotic Stresses in Mothbean [Vigna aconitifolia (Jaeq.) Marcchal] Germplasm. Int.J.Curr.Microbiol.App.Sci. 9(05): 1243-1249.

doi: https://doi.org/10.20546/ijcmas.2020.905.138 